\title{
Unsettled Objects: Books, Cultural Politics, and the Case of Reading the Country
}

\section{Mark Davis}

In the end, there is always this desire to create: to break through silence into form. ${ }^{1}$

Early on in Krim Benterrrak, Stephen Muecke and Paddy Roe's Reading the Country, Muecke, the book's narrator, makes an observation about the role of books. He asks, 'What are books for? The famous literary critic, I.A. Richards, had one way of putting it: "A book is a machine for thinking with".' Muecke continues:

A book is like an organic machine in a production line of other machines: conceived in a typewriter, gestated in a publishing house, born on a press, consumed in the press, read by people who have been through the schooling machine. It can pick you up in one thinking spot and take you to another one. It's like a ute. ${ }^{2}$

Mueke's observation is one of several about the function of books in a book that fixates on its own status as a cultural object. A few pages further on he quotes a speech he gave at Broome in the lead up to the creation of the then-proposed book:

All this to contribute to one small rectilinear object-a book. An object to be promoted, circulated, sold and read. A book is a little communicative item which is destined to be shunted around; bought, borrowed, stolen and ending 
up in places the authors would never have imagined. It is only valuable as long as it is travelling or as long as eyes are travelling across its surfaces. It's like a nomad in the sense that it belongs to a certain territory, yet only lives if it is made to move and to be seen to be going somewhere - perhaps putting on a fine dust jacket to pick up a nice reader, for it is also an object of desire.

So my question here is what kind of book-object is this?

Reading the Country sits in a history of Australian non-fiction book publishing and, in particular, a history of books that seek social change. This got going in earnest in the late 1950 s and early 1960 s when local publishers, determined to do their bit to wrestle Australian public culture from the arms of the British, many of them working in British-owned firms, started to get serious about publishing local non-fiction on affairs of the day. Books such as Robin Boyd's Australian Ugliness (1960), the Peter Coleman edited collection Australian Civilisation (1962) and Donald Horne's The Lucky Country (1964) were the result, and foreshadowed a gathering 'new nationalism'. 4 Then came the radical critiques of the 1970s; books like Humphrey McQueen's A New Britannia (1970), John Docker's Australian Cultural Elites (1974), Anne Summers' Damned Whores and God's Police (1975) and Miriam Dixson's The Real Matilda (1976), among many others. Reading the Country is part of another formation again, written out of a 'poststructuralist ... movement'; Australian culture seen through the eyes of continental critical theory. ${ }^{5}$

Reading the Country was published at a moment, too, when independent presses were starting to make their presence felt in no uncertain terms. Independent publishing has always been a feature of the Australian publishing landscape. Rigby, Jacaranda and Sun Books are among the proud independent presses of the 1950 and 1960 s. But there was something more reckless and experimental in the independent publishing of the 1970s. Fremantle Arts Centre Press (FACP) was among many new presses founded to break moulds, such as the Alternative Publishing Cooperative Limited, Outback Press, Wilde and Woolley, and McPhee-Gribble. As FACP publisher Ray Coffey has said, one motivation for publishing was the 
'enormous number of current issues that are, so far, underrepresented in publishing. ${ }^{6}$

But Reading the Country belongs to another cultural conversation as well, and sits in another important tradition in Australian non-fiction publishing. It is one of around 769 non-fiction books published between 1960 and 2000 (inclusive) that had Aboriginal culture as their topic. ${ }^{7}$ Before that, a handful of non-fiction books by and about Aborigines were published through the first half of the twentieth century, such as David Unaipon's Native Legends (1929), A.P. Elkin's The Australian Aborigine: How to Understand Them (1938), Clive Turnbull's Black War: The Extermination of the Tasmanian Aborigines (1948), and Unaipon's My Life Story (1954). ${ }^{8}$

It was only in the 1960 s that rates of publication in the area began to rise to between 14 and 17 per year, increasing to a rate of around 30 to 35 titles per year by the end of the 1990 . The vast majority of these books were published by a handful of publishers: Angus and Robertson and Rigby in the 1960s, then university presses, small independents and Penguin Books in the 1970 s and, in the 1980s, Allen and Unwin and the three major specialist Indigenous presses, Aboriginal Studies Press (founded in the 1980 os as part of the Australian Institute for Aboriginal Studies, which had itself been a prolific publisher of titles through the $1960 \mathrm{~s}$ and 1970s), IAD Press and Magabala books. FACP was a significant contributor to Indigenous non-fiction book publishing, with nineteen titles in the area. Even Penguin, the only large international trade publisher to show an interest in such books in those four decades, only published twentyone. Allen and Unwin published fifty-nine, and the lion's share was published by the three main specialist Indigenous publishers, which together published 211 titles, 160 of them by Aboriginal Studies Press and, before its inauguration, the AIAS.

This area of publishing, too, went through phases. Through the 1960 s most of the books were about Aborigines. It was only in the late 196os, at the time of the citizenship referendum and W.E.H. Stanner's famous Boyer lectures that decried the silence about the presence of Indigenous people in Australian history, that Aboriginal voices began to appear 
in the first person as agents of their own history. That, too, at first, was in the pages of a white-authored book-Frank Hardy's The Unlucky Australians (1968). Kevin Gilbert's Living Black (1977) was a landmark, and another book that came out of a conversation with its publisher, John Hooker at Penguin Books, who asked Gilbert to write a book about what being an Aboriginal in Australia is like. ${ }^{9}$ Even AIAS didn't publish its first Aboriginal-authored book, Jimmie Barker's Two Worlds of Jimmie Barker, until 1977. By the time Reading the Country was published, another trend had begun. This was the idea of telling Australian history from the Indigenous side, epitomised by Henry Reynolds' The Other Side of the Frontier: Aboriginal Resistance to the European Invasion of Australia, which Reynolds had first published out of his department at James Cook University in 1981, before Penguin Books ultimately decided to publish an edition in $1982 .{ }^{10}$

Reading the Country doesn't simply want to tell history from the other side. It wanted to unsettle everything about the epistemology in which it sat. As Muecke later explained:

A sea-change was happening in the humanities, I had intuitions born of my time in France in 1968; paradigms were groaning and shifting. The intellectual distance marked by the knowing subject and the object of knowledge was about to be broached from multiple directions: indigenous knowledges were starting to assume overt agency in the determinations of research agendas; the subjectivity or identity of the academic researcher was challenged and was leading to self-reflexivity, narrativisation and negotiation of one's speaking position: real friendships were beginning to count more; urgent Aboriginal political agendas were installing themselves in the quid pro quo of fieldwork relations, so that the exchange of knowledge for chewing tobacco was exposed as laughably trivial.

Anthropologically inspired protectionist and preservationist strategies were now less relevant as key Aboriginal professionals and activists, like Gloria Brennan, were emerging and asserting self-determination. ${ }^{11}$ 
It's in this context that the book questions the western-centric politics of its production, including the use of the book form. With almost every turned page the book works to defamiliarise itself as a cultural artefact, and to foreground its textual politics with respect to the living culture it records:

The dreaming is not a set of beliefs which is being lost because it is no longer valid, it is rather a way of talking, of seeing, of knowing, and a set of practices, which is as obtuse, as mysterious and as beautiful as any poetry ... This book is a record of Paddy Roe's dreaming at its most important nexus: the country itself ... Krim and I are foreign to the Plains, Paddy is foreign to the book as a European artifact, Paddy and I are foreign to painting, Krim and Paddy are foreign to the sort of writing and philosophy I have adopted to construct a unity or general direction of the book. ${ }^{12}$

That 'Paddy is foreign to the book as a European artifact' is the very business that Reading the Country seeks to negotiate. As part of these negotiations the book form is unsettled, framed in terms of the politics of nomadology (an idea Muecke attributes to Deleuze and Guattari) that are famously at the book's heart: 'A book has to be a set of traces, words going somewhere. The nomadic reader will then come along afterwards and track things up, deciphering the traces.' ${ }^{\prime 3}$

If the aim here is to unsettle and make nomadic the normal conditions of narrative, then it makes sense that Muecke is also at pains to leave behind the persona of author: Nomadic writing writes itself; its authority comes from the territory covered, not the person temporarily in charge of the pen. It cannot be imperial (like General Theory) because it has to abandon the traces it leaves behind and anyone can follow them up. But what do they find in the end? The material object, a book which is the product of reading the tracks made across a piece of country. But also an intellectual space made through the essentially nomadic practice of moving from one set of ideas or images towards another set progressively picked up on the way. If this imaginary journey will move closer to Aboriginal understandings of a part of Australia it is not for 
one person to say. The book can only be a white man's artifact in the end, but Paddy Roe's texts can be read independently (and must be read) as paradoxically included in the book, and thus incorporated in the broader culture, but extending before and beyond the covers (already crossing the country before the book was thought of), one word after the other like footsteps: lively spoken words. ${ }^{14}$

It's perhaps fitting that in the context of the physicality of Reading the Country its famous nomadology is itself fugitive. The book's subtitle, 'Introduction to Nomadology', appears on its half-title and title pages but not on its cover. A happenstance play of presence and absence, perhaps.

Just about every Australian non-fiction cultural politics book, from The Australian Legend on, seeks in some way to rewrite national identity. ${ }^{15}$ Paddy Roe, whose book Gularabulu: Stories from the West Kimberley (1983), edited by Muecke and one of FACP's first non-fiction books about Aborigines, supplies the disruptive voice to unsettle received notions of Australian history and its present that are a target of Reading the Country. ${ }^{16}$ In one important passage in Reading the Country Roe tells the story of how he avoided being stolen as a child:

when he see them -

my mother said, 'Hello, this is a p'liceman coming back from La Grange' - they come back from La Grange, seecome back-

'Hello,' he said, after-

my mother said, 'What I gonna do with this little boy?'so my mother ooh he think about something he tell the old man, Get up get up get up,' he said-

(Growl) 'What for,' he-

'P'lice coming'-

ah they took the canvas outa the old man (Laugh) an',

'Come here boy,' he said -

so he put me there, 'Lay down'-

rolled me up-

wind me up an' mother was sitting on me like a swag here's a p'liceman coming around the corner now- 
'Hello,' he said-

'Good Morning'-

an' old fella sitting up just having a drink of tea too$\mathrm{mm}-$

'Any piccaninnies?' he asked, you know-

'Any piccaninnies?'-

'No, we got no pic-

nothing'-

'Where you going?'-

'Oh, we goin' walkabout, now, bush'-

'Yeah, all right, goodbye,' he say-

'We can see that, you no got nobody', but I was there (Laugh) ${ }^{17}$

Roe's mother is one of the few women mentioned in Reading the Country. Her conversation with Roe's father about how to hide young Paddy, itself unsettling, is presented as part of the happenstance bricolage (a term Muecke uses throughout) of the book, and carries significant political weight as a retelling of one incident in protectionism from the 'other side'. In another passage Roe tells the story of his wife's first pregnancy:

So we just gettin' ready to go you know oh we started off 'bout-

from here to the building old woman, my old woman get sick'Oh,' he tell me, 'I get sick little bit'(Soft) 'Oh, what wrong?' I say-

'I dunno,' he say, 'must be that honey, waladja'-18

As Muecke has explained, this story is told in a 'in a very specific cultural and political context'. It is a story about a 'conception dreaming', and 'political because this dreaming will attempt to establish the daughter's custodianship of that country in the context of actual Broome land-rights claims and counter-claims'.19

Paddy Roe talks of many other things of course. Not every Indigenous utterance has to be weighted with spiritual or political import, which is itself one of the ways Aboriginality is constructed. The everyday banalities of what Roe and his 
friend Butcher Joe (Nangan), along with Mueke and Krim Benterrak do and say-opening gates, finding water, being silent, telling stories, walking, drinking tea-are some of the best parts of the book since they engage and frame experience on their own terms, and help this reader, at least, enter into imagining what the quotidian business of being Indigenous and in country is like. Reading the Country is in these ways part of an emerging conversation about being stolen and the loss of country, and about the everyday banalities of living self-aware, or not, as an Aboriginal, that is central to another important trend in Australian Indigenous non-fiction publishing. From the late 1970 s on, life stories by relative unknowns, such as Jimmie Barker's Two Worlds of Jimmie Barker: The Life of an Australian Aboriginal 1900-1972 (1977), Ella Simon's Through My Eyes (1978), Elsie Labumore Roughsey's Aboriginal Mother Tells of The Old and The New (1984), Sally Morgan's controversial My Place (1987), Glenyse Ward's Wandering Girl (1987), and Ruby Langford Ginibi's Don't Take Your Love To Town (1988), became an important part of the publishing landscape. ${ }^{20}$ Tim Rowse cites Don't Take Your Love to Town as an important site of negotiation in the question of what constitutes Aboriginality, where the 'category "Aborigines", Rowse argues, following Bain Attwood and others, is understood as 'an artifact of the colonial process'. ${ }^{21}$

But in the same cultural moment as these unsettling, self-reflexive conversations about the conditions of Australian Aboriginality were engaging readers, other conversations and other negotiations were taking place that sought to reinscribe older notions of Aboriginality and white settler patronage. Reading the Country was published in 1984, which is the year mining magnate Hugh Morgan made the speech that he later said 'really got things wheeling' in terms of coalescing opposition to Indigenous rights struggles. ${ }^{22}$ The speech, which Andrew Markus has said 'in important respects prefigured some of the views later expounded by Tim Fischer, Pauline Hanson, and David Oldfield, amongst other politicians of the right', ${ }^{23}$ proclaimed the view that Australia was a Christian society in which calls for Aboriginal land rights were not justified, and raised the proposition that to grant such rights would potentially be to also license 'infanticide, cannibalism, and ... 
cruel initiation rites', and that for a Christian Aborigine such a move would represent 'a symbolic step back into the world of paganism, superstition, fear, and darkness'. ${ }^{24}$ Another high-profile speech given that year, by historian Geoffrey Blainey (who had provided background research for Morgan's speech), would become equally famous for its attacks on Asian immigration. Both speeches singled out a self-interested elite comprised of bureaucratic, media and academic types, as culprits for the problems that had arisen - the 'Aboriginal Affairs Industry' as Morgan called it - and contrasted their claims against a vision where the best way forward for Australia was, as Morgan put it, 'to treat all Australians equally'.25

Reading the Country was, then, published at a hinge moment in recent Australian cultural politics. The oppositions drawn in these 1984 speeches between 'equal rights' and 'special treatment', mainstream and elite, reasoned centre and unreasoned other, would become definitive in battles over the Australian bicentennial celebrations, the Stolen Generations, Aboriginal deaths in custody, the Mabo and Wik native title judgments, and the Northern Territory Intervention. The related difference between self-responsible individuals and 'rent seekers' is pivotal, too, in economic debates about the role of government and that of markets. None of which is to suggest that such debates have been conclusive. The very definition of Australian postcolonialism, as Ken Gelder and Jane Jacobs have shown, is in the inconclusiveness of ongoing transactions between Indigenous and settler cultures. ${ }^{26}$ This lack of a conclusion arises at least in part because of the ongoing resistance of Aborigines and their supporters to the opposing claims of settlers and settlement. That Reading the Country is something of an ageless book, that still looks and feels contemporary and relevant, from its text to Benterrrak's artwork, is perhaps because it positions itself at every level of the ongoing struggle to unsettle these conditions of settlement. Even if, as Reading the Country knows, every impulse towards unsettlement and nomadism, and towards un-bookishness, carries its own trace of, and is ultimately ensnared in, those cultures that it seeks to resist, of settlement, authority and books. 


\section{Notes}

Krim Benterrak, Stephen Muecke and Paddy Roe, Reading the Country:

Introduction to Nomadology, 2nd revised edition, Fremantle Arts Centre Press, Fremantle, 1996 [1984]), p. 15.

Ibid., p. 24 .

3 Ibid., p. 26.

4 James Curran and Stuart Ward, The Unknown Nation: Australia After Empire, Melbourne University Publishing, Melbourne, 2010.

5 Benterrak, Muecke and Roe, p. 255.

6 In Louise Poland, 'An Enduring Record: Aboriginal Publishing in Australia 1988-1998', Australian Studies, vol. 16, no. 2, Winter 2001, pp. 83-100, p. 97.

7 Mark Davis, 'The "Cultural Mission" in Indigenous Non-fiction book Publishing in Australia 1960-200o', Journal of Australian Studies, 2017, pp. 1-22. http:// dx.doi.org/10.1080/14443058.2017.1383295.

8 David Unaipon, Native Legends, Hunkin, Ellis and King, Adelaide, 1929; A.P. Elkin, The Australian Aborigine: How to Understand Them, Angus and Robertson, Sydney, 1938; Clive Turnbull, Black War: The Extermination of the Tasmanian Aborigines, Cheshire, Melbourne, 1948; David Unaipon, My Life Story, Aborigines Friendly Association, Adelaide, 1954.

9 Geoffrey Dutton, A Rare Bird: Penguin Books in Australia 1946-96, Penguin, Melbourne, 1996, pp. 135-6.

10 Mark Davis, 'Making Aboriginal History: The Cultural Mission in Australian Book Publishing and the Publication of Henry Reynolds's The Other Side of the Frontier', in Resourceful Reading: The New Empiricism, eResearch, and Australian Literary Culture, ed. Katharine Bode and Robert Dixon, Sydney University Press, Sydney, 2010, pp. 176-93.

11 Stephen Muecke, 'Visiting Aboriginal Australia', Postcolonial Studies, vol. 2, no. 1, 1999, pp. 49-54, pp. 49-50.

12 Benterrak, Muecke and Roe, p. 19.

13 Ibid., pp. 26-7.

14 Ibid., p. 27.

15 Russel Ward, The Australian Legend, Oxford University Press, Melbourne, 1958.

16 Paddy Roe, Gularabulu: Stories from the West Kimberley, ed. Stephen Muecke, Fremantle Arts Centre Press, Fremantle, 1983.

17 Benterrak, Muecke and Roe, pp. 48-9.

18 Ibid., p. 130.

19 Muecke, 'Visiting Aboriginal Australia', p. 51.

20 Jimmie Barker, Two Worlds of Jimmie Barker: The Life of an Australian Aboriginal 1900-1972, AIAS, Canberra, 1977); Ella Simon, Through My Eyes, Rigby, 1978; Elsie Labumore Roughsey, Aboriginal Mother Tells of The Old and The New, McPhee-Gribble, Melbourne, 1984; Sally Morgan, My Place, Fremantle Arts Centre Press, Fremantle, 1987; Glenyse Ward, Wandering Girl, Magabala, Broome, WA, 1987); Ruby Langford Ginibi, Don't Take Your Love to Town, Penguin, Melbourne, 1988.

21 Tim Rowse, After Mabo: Interpreting Indigenous Traditions, Melbourne University Press, Melbourne, 1993, pp. 83-103.

22 In Andrew Markus, Race: John Howard and the Remaking of Australia, Allen and Unwin, Sydney, 2001, p. 60.

23 Ibid.

24 Ibid., p. 61.

25 Ibid., p. 62.

26 Ken Gelder and Jane M. Jacobs, Uncanny Australia, Melbourne University Press, Melbourne, 1998, p. 22. 